\title{
ENGLISH TABOO WORDS IN SEX EDUCATION TV SERIES
}

\author{
Cindy Eliza Ramadhani Lubis, Syahron Lubis, Dian Marisha Putri \\ Universitas Sumatera Utara (USU), Medan, Indonesia \\ E-mail: cindyelizalbs@gmail.com
}

Received: 24 July 2020

Accepted: 02 December 2020

\begin{abstract}
The purposes of this research are to determine the types of taboo words, the functions of taboo words, and in what context taboo words are uttered by the characters in the TV series. This study employed descriptive qualitative method. The sources of the data were 8 videos from the first season of Sex Education TV series and their transcripts. In analyzing the data, the theory of Wardhaugh (2014) was used to describe types and functions of taboo words and the theory of Fromkin (2005) to describe in what context taboo words are uttered in the TV series. The results of this research show that there are data of taboo words which are categorized into seven types; they are sex term, death, excretion, bodily function, religious matter, mother-in-law, and the left hand. The findings suggest that the characters use taboo words mostly to draw attention and to show contempt.
\end{abstract}

Keywords: taboo words, TV series, sex education.

\section{Introduction}

Language has always been an important source of communication and people use it in daily conversation. Language is ultimately important because it enables humans have the ability to communicate and interact with one another. Some people may prefer to use language that has a strong impact to express their mood such as when they are happy, sad, or angry. For instance, people sometimes use certain kind of words that are considered as bad language which is actually inappropriate to be used.

One of the ways to express their feelings or describe something is by saying taboo words. Taboo is a cultural or religious custom that does not allow people to do, use, or talk about a particular thing as people find it offensive or embarrassing, taboo words are words that many people consider offensive or shocking, for example, because they refer to sex, the body or people's race.

Taboo word becomes a phenomenon in today's life, it occurs in most languages because every member of society has different ways to express their mind in language. The existence of taboo words can be found from various sources such in movies, song lyrics, social media, and television shows or television series.

Taboo word is a part of informal language and exists in most of our society. The term taboo was borrowed from Tongan, a Polynesian language means forbidden. Wardhaugh (2014:229) mentions that taboo is related to the culture meanings, which are expressed in language. It means that language is used to avoid saying certain thing which is considered immoral and improper to the certain thing.

Based on the explanation above, the purposes of this study are toare to determine the types of taboo words and the functions of taboo words by using Wardhaugh's theory (2014), 
and in what context taboo words which uttered by the characters in Sex Education TV series by using Fromkin's theory (2005).

\section{Literature Review}

There are some previous researches about taboo words that have been done. Three of them were adopted as a comparison to fill the gap in this study. Baruch, Prouska, OlliereMalaterre, and Bunk (2017) talked about swearing at work. The purpose of the journal is to explore the use and misuse of swearing in the workplace. The authors interviewed 52 lawyers, medical doctors and business executives in the UK, France, and the USA. The findings of the research imply that although workplace swearing cannot be recommended, or not even tolerated, many employees have a natural need to swear, either as a stress release mechanism, to emphasize an issue or to build rapport.

Kurniawati and Harjanto (2019), in their journal talked about English taboo words which were produced by the teenagers in season 2 of Stranger Things TV series. Azzaro's theory was used to classify the types of taboo words and the functions of taboo words that found in the TV series Stranger Things. The results of the research show that in term of types of taboo words, religious swearing is the most frequently used by the teenage characters in TV series Stranger Things season 2, followed by scatological swearing, sexual swearing, and mental swearing. The least frequently is physical swearing. For the functions of taboo words, the researcher found that swearing is the most used rather than insulting.

In their journal, Robati and Zand (2017) investigated the types of taboo terms using Cabrera's theory and strategies applied based on Davoodi's in her translation in the novel The Absolutely True Diary of a Part-Time Indian by Sherman Alexie. For the type of taboo terms, sexual reference/body part are mostly used among the other types, followed by physical condition, violence, animal name, drugs, scatology/urination, filth, blasphemous, and death/killing. For the applied strategies for translating taboos, substitution is the most frequently used followed by taboo for taboo, censorship, and euphemism. Thus, the gap lies on the application of the theory in which Robati and Zand used Crabrera's theory whereas the present research makes use of Wardhaugh's theory.

\section{Research Method}

This study was conducted by using a descriptive qualitative method. By such a method the use of taboo words found in the script of Sex Education TV series was described. Taboo words as the data of this study will be chosen from the script and collected through note taking as the method of collecting data. Then, the data will be analyzed based on the problems of study proposed.

This study uses a British comedy-drama television series on Sex Education, which is an original program distributed by Netflix. The first season of the series released on Netflix was adopted as the data through the dialogues spoken by the characters in Sex Education TV series. The dialogues which contain many taboo words were obtained from www.subscene.com. Verbal data can be found in utterances spoken by the characters from the series, while nonverbal data can be seen through facial expression, gestures, tone and physical contact between the characters.

According to Miles, et.al. (2014: 46), data collection is divided into four methods: observation, questionnaire, interview, and study of document. In this research, documentation method was used to collect the data. Steps in collecting the data are as follow: 
1. Downloading the episodes of Sex Education TV series season 1. The researcher downloaded the series from www.netflix.comonJanuary 23, 2020.

2. Downloading the transcription of the series fromhttps://subscene.com/subtitles/sexeducation-first-season/english on January 23, 2020.

3. Watching all episodes from the first season of Sex Education TV series and reading the full transcription text.

4. Checking the accuracy of the transcription text and the videos of the series.

5. Listing all the utterances of the characters to be analyzed later on.

6. The next step is grouping the data into types and function of taboo words.

7. The last step is analyzing them based on the theory.

\section{Result and Discussion}

\subsection{Data Analysis}

\subsubsection{Sex Term}

Eric : I mean, can you even get hard-on?

Otis : Of course I can. I'm not fucking eunuch, all right?

The word fucking is usually used in sexual activity. The main meaning of fuck is "have sex". This word is considered obscene but is generally used in many informal and familiar situations, which refer to taboo word when people use it in front of public. This word is the most taboo and powerful rude in English. The word fucking in this script used by the speaker is to emphasize an emotion. Otis is annoyed with Eric because Eric always asks him whether he masturbated in the morning. Eric said that Otis didn't even try to masturbate and said that Otis has never got an erection. Then, Otis attracts Eric's attention with a taboo word. In this case, Otis is annoyed with Eric because Eric says that Otis can't get an erection like a eunuch. Therefore, the word fucking is uttered by Otis to attract Eric's attention.

1. Physical context in this conversation happens while Otis and Eric are riding their bicycles from Otis' house to school. They are talking on a very quiet street that surrounded by many trees.

2. Epistemic context as we know that epistemic refers to the background of information shared by speakers. Here is the basic knowledge that makes the situation why Otis says a taboo word to Eric. The basic assumption we can get is that Eric annoys Otis by saying that his friend has never got an erection.

3. Linguistic context here is Otis wants to make his friend understand that he is not a eunuch.

4. Social context here is informal and a bit rude, there is a friendship norm that is generally happens among friends, whether it is close friends or casual friends.

\subsubsection{Death}

Jackson : There' somebody in this crowd who is special to me. And no, it's not you Mr. Groff. This person is pretty damn incredible.

The utterance damn in this conversation refers to taboo word, the utterance is considered to death term. The word damn that used by Jackson is impolite when it used in front of public. In this situation, Jackson asks all students to gather in the school canteen because he wants to ask Maeve to be his girlfriend in front of everyone. When Jackson wants to make an 
announcement, he explains Maeve that she is a very incredible girl with taboo word. The word damn in this case is to draw attention.

1. Physical context of this conversation happens when Jackson is standing on a table in the school canteen accompanied by a school band and all students.

2. Epistemic context of this conversation happens when Jackson describes what he really thinks about Maeve.

3. Linguistic context of this conversation is that the utterance form used here is death term that is uttered by Jackson to draw attention.

4. Social context of this conversation is informal. This conversation refers to the social relationship as friends between the speaker and the listener.

\subsubsection{Excretion}

Adam

: Give me that Curly Wurly, or I will break your face.

Eric : Okay.

Adam

: Aah! Yeah, see you tomorrow, shit biscuit!

The word shit refers to taboo word because it refers to human excretory. This word is impolite and rude to be used in front of public. In this case, the word shit that is uttered by Adam is insulting or cursing word, and shit is taboo to be spoken since this word in this conversation is used to show contempt to the listener. Adam thinks that Eric is someone worthless and cannot be respected.

1. Physical context of this conversation happens in the school hallway, Adam asks for money and Curly Wurly from Eric, and after he eats the Curly Wurly, he leaves Eric by saying shit.

2. Epistemic context of the conversation above is Adam comes and forces Eric to give him money and Curly Wurly.

3. Linguistic context in this conversation is that the utterance used by the speaker is to insult or curse his listener by saying shit.

4. Social context here is between friends, and still informal and harsh. However, there is a norm that is commonly holds among friends whether it is close friends or casual friends.

\subsubsection{Bodily Functions}

Jean : [to Remi] Take that, thunderdick.

The utterance dick is considered as taboo word because this word is a part of private body. This word is super offensive and impolite to be spoken in front of public. In this case, Jean is angry with her ex-husband, Remi, because he wants Jean to sign all books that he sent to her house and it annoys her. Then, Jean gets an idea to write her own book to prove to her exhusband that she also can write a book without Remi's intervention. Jean utters taboo word to provoke Remi's anger by write and produce her own book as if she wants to bet him.

1. Physical context of this monologue happens when Jean starts typing on her laptop in her office.

2. Epistemic context in this monologue happens after Remi called Jean and talking about Remi's books

3. Linguistic context in this conversation in that the utterance used here is taboo word that contains anger.

4. Social context here is informal and super rude and other indicates that it may have become vulgar. 


\subsubsection{Religious Matter}

$\begin{array}{ll}\text { Jean } & : \text { [inhaling] [exhaling] God, that's strong stuff. } \\ \text { Adam } & : \text { It is chronic shit. }\end{array}$

The word God in the conversation above refers to taboo word, because the word is a formal word that commonly used in a formal situation. In this conversation, the word God is not used in formal situation, but this word is used in informal situation. In this case, Jean is surprised when she smokes the cigarette which is given by Adam because it feels so strong for her. The utterance God used by Jean refers to an explanation of surprise, and Jean emphasizes her emotion to draw the listener's attention by using taboo word.

1. Physical context here happens when Adam visits Otis and meets his mother, Jean. Jean is smoking a cigarette which is given by Adam on the balcony of Jean's house that face the forests.

2. Epistemic context here happens because Adam gives Jean a cigarette and the cigarette feels so strong for Jean.

3. Linguistic context in this conversation happens to the speaker who wants to express her emotion to the listener by saying God.

4. Social context in this conversation happens between an adult and a boy in informal situation.

\subsubsection{Mother-in-Law}
Ruby (to Maeve)
: What a slag.
Olivia
: Look at the greasy hair. Maybe she can't afford shampoo.

The next brief description is the utterance slag that is spoken by Ruby means (1) a woman who has had a lot of sexual partners, (2) the word slag refers to derogatory a woman especially cruel and an unpleasant one. In this conversation, the researcher finds that the word slag that is used by Ruby is insulting word that includes swearing or cursing, and slag is taboo to be spoken since this word in this conversation is used to show contempt to the listener, and the speaker thinks that the listener is someone who cannot be respected. The utterance slag is the example of Mother-in-Law since this word means a woman who has had a lot of sexual partners. Furthermore, other evidence shows that it may have become vulgar as it shown in this context; where Ruby insults Maeve to show contempt and thinks that Maeve is someone worthless and it makes Maeve staring at her and feeling unhappy.

1. Physical context of this conversation is in front of school building, when Ruby, Olivia, Anwar, and Aimee are sitting on the bench while looking at Maeve who will enter the building.

2. Epistemic context of this conversation is when Maeve walks pass Ruby, Olivia, Anwar, and Aimee to get into the school building with her greasy pink hair.

3. Linguistic context in this conversation is that the utterance used by the speaker is to insult or offend the listener by calling slag.

4. Social context in this conversation is informal and rude. However, there is a norm that is commonly holds among friends whether it is close friends or casual friends.

\subsubsection{The Left Hand}

$\begin{array}{ll}\text { Sarah } & \text { : You any good at quizzes? } \\ \text { Maeve } & \text { : No. }\end{array}$




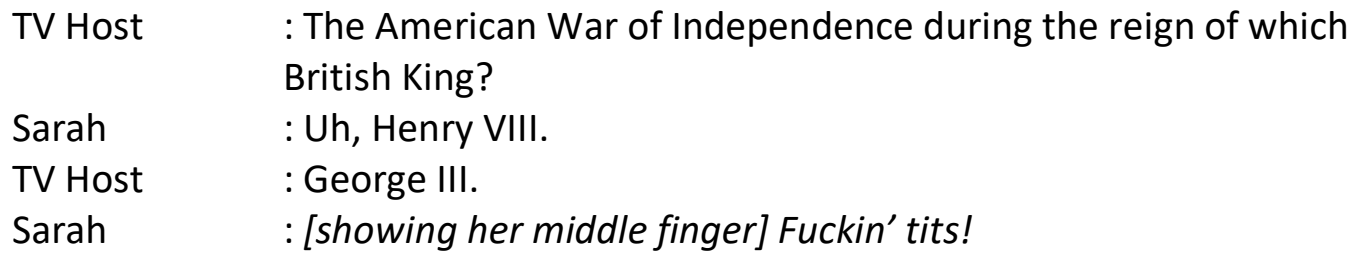

The action of showing a middle finger is the symbol of sexual intercourse and this action is considered taboo. This symbol is super rude and impolite behavior when it shown in front of public. In this case, Sarah is annoyed because she said the wrong answer to a TV show. She thought that her answer to the quiz is right but turns out it is wrong. Moreover, Sarah also uses the words fucking tits that are considered as taboo words. The action of showing a middle finger and saying the words fucking tits that are expressed by Sarah are to insult or to show contempt.

1. Physical context of this conversation is in the lobby of an abortion clinic where Maeve and Sarah are watching TV while waiting for their turn to enter the room of the clinic.

2. Epistemic context of this conversation happens when Sarah says the wrong answer to the quiz from a TV show.

3. Linguistic context in this conversation is that the behavior and the utterances expressed by Sarah are to insult the TV host.

4. Social context here is informal and super rude and other evidence indicates that it may have become vulgar.

Table 1: Percentage of Types of Taboo Words in Sex Education TV Series Season 1

\begin{tabular}{|l|c|c|}
\hline \multicolumn{1}{|c|}{ Types of Taboo Words } & Occurance & Percentage \\
\hline Sex Term & 64 & $33.3 \%$ \\
\hline Death & 9 & $4.7 \%$ \\
\hline Excretion & 32 & $16.7 \%$ \\
\hline Bodily Function & 54 & $28.12 \%$ \\
\hline Religious Matter & 24 & $12.5 \%$ \\
\hline Mother-in-Law & 8 & $4.16 \%$ \\
\hline The Left Hand & 1 & $0.52 \%$ \\
\hline \multirow{2}{*}{} & 192 & $100 \%$ \\
\hline
\end{tabular}

The table above shows number of taboo words used in of Sex Education TV Series season 1 and there are 192 data of taboo words found from the series script. It is concluded that the most dominant type of taboo words used in the script of Sex Education TV series season 1 was sex term where the percentage reached $33.3 \%$ with 64 data, followed by taboo of bodily function with 54 of 192 data where the percentage for about 28,12\%, excretion is 32 of 192 data with the percentage for about $16,7 \%$, religious matter is 24 of 192 data with the percentage reached $12.5 \%$, death is 9 of 192 data with the percentage for about $4.7 \%$, motherin-law is 8 of 192 data with the percentage $4.16 \%$, and the last is the left hand is 1 of 192 data with the percentage for about $0.52 \%$.

The genre of TV series Sex Education which is chosen as the source of the data is teen comedy. This is a reason why function of taboo word "to mock authority" is not found from the script. Genre of teen comedy contains fun, silly, common events in daily life. 


\section{Conclusion}

Based on the data analysis and findings presented above, there are seven types of taboo words and three functions of taboo words. There are 192 data of taboo words found in the source of data which are categorized into the seven types of taboo words, they are sex term, death, excretion, bodily function, religious matter, mother-in-law, and the left hand. The total amount of all taboo words used in Sex Education TV Series season 1 are 192 data where 64 data for sex term, 54 data for bodily function, 32 data for excretion, 24 data for religious matter, 9 data for death, 8 data for mother-in-law and 1 data for the left hand. Each category of taboo words has its own function which is based on the context why and how taboo words be expressed. Functions of taboo words are divided into these following items: to draw attention, to show contempt, and to be provocative.

\section{References}

Baruch, Y., Prouska, R., Ollier-Malaterre, A. and Bunk, J. (2017). Swearing at work: the mixed outcomes of profanity. Journal of Managerial Psychology. 32 (2), 149-162. https://psycnet.apa.org/record/2017-09123-002.

Fromkin, Victoria. (2005). An Introduction to Language. Stamford: Thomson Corporation.

Kurniawati, Theresia R. A \& Hardjanto, Tofan Dwi. (2019). Taboo Words in the TV Series Stranger Things. Lexicon: Journal of English Language and Literature. 6 (1), 87-97. https://www.researchgate.net/publication/344179911_Taboo_Words_in_the_TV_Se ries_Stranger_Things.

Miles, Matthew, et al. (2014). Qualitative Data Analysis: A Method Sourcebook: Third Edition. London: Sage Publications.

Robati, Fatemeh Zahra Nazari \& Zand, Fatemeh. (2018). Translation of Taboos: The Absolutely True Diary of a Part-time Indian. International Journal of Applied $\begin{array}{llll}\text { Linguistics \& English Literature. } & 7 & \text { (3), }\end{array}$ https://www.journals.aiac.org.au/index.php/IJALEL/article/view/4246

Wardhaugh, Ronald. (2014). An Introduction to Sociolinguistics (Seventh Edition). Oxford: Wiley Blackell. 